\title{
PDA-CAD method for the determination of magnesium, pyridoxine and thiamine in a dietary supplement supported by analytical quality by design methodology
}

\section{Milena Rmandić ${ }^{1}$, Miloš Rađenović ${ }^{2}$ Jovana Stanković ${ }^{3}$, Ana Protić ${ }^{1}$,

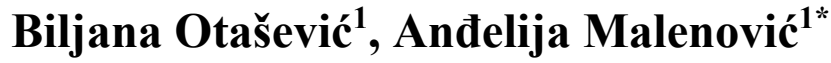

${ }^{1}$ University of Belgrade - Faculty of Pharmacy, Department of Drug Analysis, Vojvode Stepe 450, 11221 Belgrade, Serbia

${ }^{2}$ Roche d. o. o., Milutina Milankovića 11a, 11070 Belgrade, Serbia

${ }^{3}$ Goodwill Pharma, Matije Gupca 14, 24000 Subotica, Serbia

*Corresponding author: Anđelija Malenović, E-mail: andjelija.malenovic@pharmacy.bg.ac.rs

\begin{abstract}
In this research, Analytical Quality by Design (AQbD) methodology was used to develop the HILIC-PDA-CAD method for the determination of magnesium, pyridoxine and thiamine content in a dietary supplement. Experiments were conducted on the Dionex Ulitimate 3000 HPLC system with PDA and CAD detectors. Separations were performed on the ZIC-HILIC PEEK column $(100 \times 4.6 \mathrm{~mm}, 5 \mu \mathrm{m})$ with a mixture of acetonitrile, acetone and ammonium acetate/ammonium formate aqueous solution $(48: 12: 40, \mathrm{v} / \mathrm{v} / \mathrm{v})$ as the mobile phase. The detection was performed at $220 \mathrm{~nm}$. The optimal settings of CAD were defined with the one-factor-at-atime approach: evaporation temperature $50^{\circ} \mathrm{C}$, filter constant $10 \mathrm{~s}$, pressure gas 60 psi. The influence of qualitative (salt type) and quantitative factors ( $\mathrm{pH}$ and salt concentration) on the magnesium retention factor, $k_{\mathrm{Mg}}$ and the selectivity factor between pyridoxine and chloride anion, $\alpha_{\mathrm{B} 6 / \mathrm{Cl}^{-}}$, was tested using the I-optimal design. The design space was defined by Monte Carlo simulations and model coefficients' errors were propagated with the aim of identifying the conditions that meet the following criteria: $k_{\mathrm{Mg}}<4$ and $\alpha_{\mathrm{B} 6 / \mathrm{Cl}}>3.5$, with the probability $\pi=95 \%$. From the derived 2D-Design Space graph, $95 \mathrm{mM}$ of ammonium formate $\mathrm{pH} 4.4$ was selected as the optimal composition of the aqueous phase. The method was validated and its reliability in routine application was confirmed.
\end{abstract}

Keywords: HILIC-PDA-CAD, magnesium, pyridoxine, thiamine, AqbD

doi.org/10.5937/arhfarm71-32093 


\section{Introduction}

Dietary supplements are defined as orally applied products that might contain vitamins, minerals, amino acids, fiber, enzymes, herbs or botanicals, algae or macroscopic fungi. They are available as pills, tablets, capsules, powders, energy bars, and liquids and must be labeled as dietary supplements. They are used as compensation for diets, medical conditions, or eating habits that limit the intake of essential vitamins and nutrients, to boost energy or to get a good night's sleep, also to counter a sudden drop in estrogen levels at postmenopausal women (1). The regulatory framework on dietary supplements in the Republic of Serbia is provided by the Food Safety Law (2) and Rules on the health suitability of dietary products (3). They are regulated as foods rather than as pharmaceuticals, and consequently are not as closely monitored as it may be necessary. Therefore, the quality, efficacy and safety of the marketed dietary supplements can be questionable.

The combination of magnesium, thiamine and pyridoxine in a dietary supplement is recommended in cases of cramps and muscle pain, problems with constipation due to lazy bowels, increased exercise in athletes, fatigue and weakness, nervous tension and irritability, postmenopausal syndrome, migraine and other types of headaches (4). A comprehensive literature survey indicated that the analytical method for the simultaneous analysis of such solute mixture had not been previously published. The aim of this research was the development and validation of the first HILIC-PDA-CAD method for the estimation of magnesium, thiamine and pyridoxine content in dietary supplements.

A non-chromophore dependent detection technique, such as Charged Aerosol Detector (CAD), was the reasonable choice, since magnesium cation lacks UV absorption. CAD is a mass-dependent detector, suitable for all non-volatile and the majority of semi-volatile analytes, that generates the response unrestricted with spectral or physicochemical properties of the detected solute (5). Since nebulization and evaporation processes precede detection in $\mathrm{CAD}$, it is of utmost importance that only volatile constituents are combined in the mobile phase. It is desirable to use large amounts of organic solvents, like acetonitrile, that will abate mobile phase viscosity and have a favorable effect on the nebulization, resulting in a greater number of particles. Furthermore, the evaporation of the formed aerosol will be facilitated, producing a large number of dry particles and increasing response intensity and detector sensitivity (6-8). When necessary, volatile mobile phase additives, such as the formic acid, acetic acid, trifluoroacetic acid, ammonium acetate or ammonium format can also be used. Hydrophilic Interaction Liquid Chromatography (HILIC) is a useful novel approach for the effective separation of compounds exhibiting high polarity characteristics. Polar stationary phases (silica, amino, diol, zwiterionic or cyano) are employed along with RPHPLC similar mobile phases. A desirable mobile phase comprises more than $70 \%(\mathrm{v} / \mathrm{v})$ of organic solvent, mainly acetonitrile, and a low content of water or aqueous solution of volatile buffer, providing better sensitivity and adequate retention for polar ionic compounds. The high volatility of HILIC mobile phases facilitates evaporation and makes this chromatographic technique particularly suitable for coupling with $\operatorname{CAD}(9,10)$. 
Analytical Quality by Design (AQbD) is a cost-effective strategy to obtain robust and reliable analytical methods in line with the set of performance criteria and quality requirements adopted in the Analytical Target Profile (ATP). The outcome of implementing quality and risk assessment in the method development phase is the possibility of flexible moving of method parameters within the computed Design Space (DS) $(11,12)$. The AQbD approach is based on detailed understanding of the analytical procedure and all the potential risks leading to method failure. The focus of AQbD is the definition of the DS within which Critical Method Attributes (CMAs) meet the defined criteria with an acceptable level of probability $(\pi)$, while small, intentional drifts of Critical Method Parameters (CMPs) have no significant effect on them. Consequently, the analytical method is not defined by one single combination of method parameters, but with the set of experimental conditions within the DS.

\section{Experimental}

\section{Materials and chemicals}

HPLC grade acetonitrile and acetone (Fluka, Sigma-Aldrich, Germany), ammonium format (Fluka, Sigma-Aldrich, Germany), ammonium acetate (Fluka, SigmaAldrich, Germany) and water filtered through Simplicity 185 (Millipore, Billerica, MA) were utilized for the mobile phases' preparation. The aqueous phase $\mathrm{pH}$ was adjusted within the 4.25- 5.75 range with formic acid (98\%, Fluka, Sigma Aldrich, Germany) or glacial acetic acid (Fluka, Sigma-Aldrich, Germany). For the preparation of stock solutions for method validation magnesium oxide ( $99 \%$ purity, Sigma-Aldrich, USA), reference standards of thiamine $\mathrm{HCl}$ and pyridoxine $\mathrm{HCl}$ (LGC standards, UK), as well as Magnezijum 375 Plus B6 ${ }^{\circledR}$ capsules (Inpharm d.o.o, Serbia), were used. One capsule of Magnezijum 375 Plus B6 $6^{\circledR}$ contains magnesium (375 mg magnesium oxide - MgO), pyridoxine $(1.4 \mathrm{mg}$ pyridoxine $\mathrm{HCl})$ and thiamine $(1.1 \mathrm{mg}$ thiamine $\mathrm{HCl})$.

\section{Apparatus and experimental conditions}

All the experiments were conducted on the Dionex Ultimate 3000 HPLC system (Thermo Scientific, USA) with PDA (Photodiode Array Detector) and CAD (Corona Veo-Charged Aerosol Detector) detector (Thermo Scientific, USA). Separations were performed on the SeQuant ZIC- HILIC $(100 \times 4.6 \mathrm{~mm}, 5 \mu \mathrm{m})$ (Merck, Germany) column.

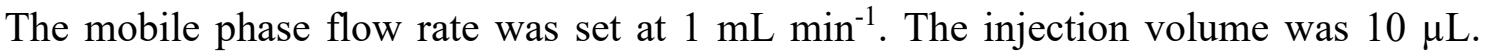
During the optimization of chromatographic conditions, CAD parameters were set at the following values: evaporation temperature $50^{\circ} \mathrm{C}$, gas pressure $60 \mathrm{psi}$, data collection rate $10 \mathrm{~Hz}$, filter constant $10 \mathrm{~s}$ and function 1. PDA detector was set at $220 \mathrm{~nm}$. On the basis of preliminary experiments, acetonitrile, acetone and aqueous phase ratio in the mobile phase was kept constant (48: 12: 40, v/v/v). Salt concentration in the aqueous phase ( $\left.\mathrm{x}_{1}\right)$, $\mathrm{pH}$ of the aqueous phase ( $\left.\mathrm{x}_{2}\right)$ and salt type ( $\left.\mathrm{x}_{3}\right)$ were varied according to the plan of experiments (Table I) defined by the I-optimal design using Design-Expert ${ }^{\circledR}$ software. The experimentally obtained results were analyzed by Microsoft ${ }^{\circledR}$ Excel 2013 (Microsoft Corporation, USA) and Matlab ${ }^{\circledR}$ R2018 (Mathworks, USA). 
Table I Plan of experiments and experimentally obtained response values

Tabela I Plan eksperimenata i eksperimentalno dobijene vrednosti odgovora sistema

\begin{tabular}{|c|c|c|c|c|c|}
\hline № & $x_{1}$ & $x_{2}$ & $x_{3}$ & $\alpha_{B 6 / C l}$ & $\boldsymbol{k}_{M g}$ \\
\hline 1 & 50 & 4.25 & $\mathrm{AF}$ & 3.445 & 3.71 \\
\hline 2 & 100 & 4.25 & $\mathrm{AF}$ & 2.125 & 4.46 \\
\hline 3 & 50 & 5.00 & $\mathrm{AF}$ & 4.520 & 3.91 \\
\hline 4 & 75 & 5.00 & $\mathrm{AF}$ & 3.342 & 3.20 \\
\hline 5 & 75 & 5.00 & $\mathrm{AF}$ & 3.348 & 3.18 \\
\hline 6 & 75 & 5.00 & $\mathrm{AF}$ & 3.407 & 3.16 \\
\hline 7 & 100 & 5.00 & $\mathrm{AF}$ & 2.441 & 4.83 \\
\hline 8 & 50 & 5.75 & $\mathrm{AF}$ & 3.982 & 4.07 \\
\hline 9 & 75 & 5.75 & $\mathrm{AF}$ & 3.344 & 3.84 \\
\hline 10 & 100 & 5.75 & $\mathrm{AF}$ & 3.013 & 3.81 \\
\hline 11 & 50 & 4.25 & $\mathrm{AA}$ & 3.666 & 2.98 \\
\hline 12 & 75 & 4.25 & AA & 2.740 & 3.37 \\
\hline 13 & 75 & 4.25 & $\mathrm{AA}$ & 2.740 & 3.29 \\
\hline 14 & 50 & 5.00 & AA & 5.015 & 2.88 \\
\hline 15 & 100 & 5.00 & $\mathrm{AA}$ & 2.486 & 3.66 \\
\hline 16 & 100 & 5.00 & AA & 2.472 & 3.71 \\
\hline 17 & 75 & 5.75 & AA & 4.925 & 2.55 \\
\hline 18 & 75 & 5.75 & AA & 4.929 & 2.57 \\
\hline
\end{tabular}

$\mathrm{x}_{1}$ - salt concentration in the aqueous phase $(\mathrm{mM}), \mathrm{x}_{2}-\mathrm{pH}$ of the aqueous phase,

$\mathrm{x}_{3}$ - salt type (AF - ammonium format, $\mathrm{AA}$ - ammonium acetate)

$k_{\mathrm{Mg}}$ - retention factor of $\mathrm{Mg}^{2+}, \alpha_{B 6 / C l}$ - selectivity factor between pyridoxine $\mathrm{HCl}$ and $\mathrm{Cl}^{-}$

\section{Preparation of solutions for method development and validation}

\section{Solutions for the Design Space definition}

Stock solutions of $\mathrm{MgO}$, thiamin $\mathrm{HCl}$ and pyrodoxine $\mathrm{HCl}$ were prepared in the concentration of $1 \mathrm{mg} \mathrm{mL}^{-1}$ by dissolving respective amounts of $\mathrm{MgO}$ in the $0.25 \%$ aqueous solution of formic acid, while thiamin $\mathrm{HCl}$ and pyrodoxine $\mathrm{HCl}$ were dissolved in HPLC grade water. Working solutions were prepared from the stock solution. The appropriate amounts of stock solutions were transferred to the volumetric flasks and filled up with acetonitrile-water mixture $(80: 20, \mathrm{v} / \mathrm{v})$ to attain the concentration of $200 \mu \mathrm{g} \mathrm{mL}-$ ${ }^{1}$ for $\mathrm{MgO}$ and $100 \mu \mathrm{g} \mathrm{mL}{ }^{-1}$ for both vitamins. 


\section{Preparation of the mobile phase for method validation}

The aqueous solution of ammonium format in the concentration of $95 \mathrm{mM}$ was prepared by weighing $5.985 \mathrm{~g}$ of salt, which was transferred by $600 \mathrm{~mL}$ of HPLC water to a $1000 \mathrm{~mL}$ volumetric flask. After sonication in the ultrasonic bath for 10 minutes, the solution was filled to the mark with HPLC water. The $\mathrm{pH}$ value of the $95 \mathrm{mM}$ ammonium format aqueous solution was adjusted to 4.4 with formic acid. The mobile phase was prepared by mixing $480 \mathrm{~mL}$ of acetonitrile, $120 \mathrm{~mL}$ of acetone and $400 \mathrm{ml}$ of $95 \mathrm{mM}$ ammonium format aqueous solution.

\section{Solutions for selectivity evaluation}

Selectivity was evaluated using chromatograms of colloidal silica (Fargon, Rotterdam, The Netherlands) and anhydrous lactose (Fargon, Rotterdam, The Netherlands) solutions, a solution containing $200 \mu \mathrm{g} \mathrm{mL}^{-1}$ of $\mathrm{MgO}$, as well as a sample solution with $80 \mu \mathrm{g} \mathrm{mL}^{-1}$ of pyridoxine $\mathrm{HCl}$ and $80 \mu \mathrm{g} \mathrm{mL}^{-1}$ of thiamin $\mathrm{HCl}$. Colloidal silica and anhydrous lactose solutions were prepared in the final concentration of $100 \mu \mathrm{g}$ $\mathrm{mL}^{-1}$ by treating them in the same way as the samples used for the precision evaluation of the method.

\section{Solutions for linearity testing}

Stock solution of $\mathrm{MgO}$ was prepared in the $0.25 \%$ aqueous solution of formic acid in the concentration of $1 \mathrm{mg} \mathrm{mL}^{-1}$. Working solutions were prepared in the concentrations of $100 \mu \mathrm{g} \mathrm{mL}^{-1}, 150 \mu \mathrm{g} \mathrm{mL}^{-1}, 200 \mu \mathrm{g} \mathrm{mL}^{-1}, 250 \mu \mathrm{g} \mathrm{mL}^{-1}$ and $300 \mu \mathrm{g} \mathrm{mL}^{-1}$ by dilution of stock solution with $95 \mathrm{mM}$ ammonium format - acetone -acetonitrile mixture (20:16:64, v/v/v).

Stock solutions of thiamin $\mathrm{HCl}$ and pyrodoxine $\mathrm{HCl}$ were prepared in acetonitrile water $(50: 50, \mathrm{v} / \mathrm{v})$ in the concentration of $1 \mathrm{mg} \mathrm{mL}^{-1}$. Working solutions were prepared in the concentrations of $40 \mu \mathrm{g} \mathrm{mL}^{-1}, 60 \mu \mathrm{g} \mathrm{mL}^{-1}, 80 \mu \mathrm{g} \mathrm{mL}^{-1}, 100 \mu \mathrm{g} \mathrm{mL}^{-1}$ and $120 \mu \mathrm{g}$ $\mathrm{mL}^{-1}$ by dilution of stock solutions with $95 \mathrm{mM}$ ammonium format - acetone -acetonitrile mixture $(20: 16: 64, \mathrm{v} / \mathrm{v} / \mathrm{v})$.

\section{Solutions for accuracy testing}

The mixture of Magnezijum 375 Plus B6 ${ }^{\circledR}$ capsule content (corresponding to $25 \mathrm{mg}$ of $\mathrm{MgO}$ ) and $25 \mathrm{mg}$ of $\mathrm{MgO}$ was placed into a $25 \mathrm{~mL}$ volumetric flask and extracted with the $0.25 \%$ aqueous solution of formic acid in the ultrasonic bath for 20 minutes. The volumetric flask was filled up to the volume with the previously mentioned solvent. The obtained solution was filtered through Syringe Nylon Filters, $25 \mathrm{~mm}$, with $0.45 \mu \mathrm{m}$ pore size (Waters, Milford, USA). The solvent consisting of $95 \mathrm{mM}$ ammonium format acetone -acetonitrile mixture $(20: 16: 64, \mathrm{v} / \mathrm{v} / \mathrm{v})$ was further used for dilution. Three series of three solutions corresponding to $80 \%\left(160 \mu \mathrm{g} \mathrm{mL}^{-1}\right), 100 \%\left(200 \mu \mathrm{g} \mathrm{mL}^{-1}\right)$ and $120 \%$ $\left(240 \mu \mathrm{g} \mathrm{mL}^{-1}\right)$ were used for accuracy estimation.

The mixture of Magnezijum 375 Plus B $6^{\circledR}$ capsule content (corresponding to $5 \mathrm{mg}$ of pyridoxine $\mathrm{HCl}$ or thiamin $\mathrm{HCl}$ ), $5 \mathrm{mg}$ of thiamine $\mathrm{HCl}$ or $5 \mathrm{mg}$ pyridoxine $\mathrm{HCl}$ was 
placed into $25 \mathrm{~mL}$ volumetric flasks and extracted with the solvent acetonitrile-water $(50: 50, \mathrm{v} / \mathrm{v})$ in the ultrasonic bath for 20 minutes. The volumetric flasks were filled up to the volume with the previously mentioned solvent. The obtained solutions were filtered through Syringe Nylon Filters, $25 \mathrm{~mm}$, with $0.45 \mu \mathrm{m}$ pore size (Waters, Milford, USA). The solvent consisting of $95 \mathrm{mM}$ ammonium format - acetone -acetonitrile mixture $(20: 16: 64, \mathrm{v} / \mathrm{v} / \mathrm{v})$ was further used for dilution. Three series of three solutions corresponding to $80 \%\left(64 \mu \mathrm{g} \mathrm{mL}^{-1}\right), 100 \%\left(80 \mu \mathrm{g} \mathrm{mL}^{-1}\right)$ and $120 \%\left(96 \mu \mathrm{g} \mathrm{mL}^{-1}\right)$ for each vitamin were used for accuracy estimation.

\section{Solutions for precision testing}

Magnezijum 375 Plus B $6^{\circledR}$ capsule powder corresponding to $25 \mathrm{mg}$ of $\mathrm{MgO}$ was weighed and placed into a $25 \mathrm{~mL}$ volumetric flask, extracted with the $0.25 \%$ aqueous solution of formic acid in the ultrasonic bath for 20 minutes. The volumetric flask was filled up to the volume with the previously mentioned solvent. The obtained solution was filtered through Syringe Nylon Filters, $25 \mathrm{~mm}$, with $0.45 \mu \mathrm{m}$ pore size (Waters, Milford, USA). Six working solutions were obtained from the stock solution, containing $200 \mu \mathrm{g}$ $\mathrm{mL}^{-1}$ of $\mathrm{MgO}$, and were prepared in $95 \mathrm{mM}$ ammonium format - acetone -acetonitrile mixture $(20: 16: 64, \mathrm{v} / \mathrm{v} / \mathrm{v})$.

The capsule powder was weighed to attain $5 \mathrm{mg}$ of pyridoxine $\mathrm{HCl}$ or thiamin $\mathrm{HCl}$ and was transferred into a $25 \mathrm{~mL}$ volumetric flask. The acetonitrile-water $(50: 50, \mathrm{v} / \mathrm{v})$ solvent was used for extraction in the ultrasonic bath for 20 minutes. The volumetric flask was filled up to the volume with the same solvent, and then the solution was filtered through Syringe Nylon Filters, $25 \mathrm{~mm}$, with $0.45 \mu \mathrm{m}$ pore size (Waters, Milford, USA). From that stock solution, six solutions containing $80 \mu \mathrm{g} \mathrm{mL}^{-1}$ of pyridoxine $\mathrm{HCl}$ and thiamin $\mathrm{HCl}$ were prepared in $95 \mathrm{mM}$ ammonium format - acetone - acetonitrile mixture $(20: 16: 64, \mathrm{v} / \mathrm{v} / \mathrm{v})$.

\section{The analysis of Magnezijum 375 Plus B6 ${ }^{\circledR}$ capsules}

Ten Magnezijum 375 Plus B $6^{\circledR}$ capsule contents were pulverized. From the obtained powder, capsule content corresponding to $25 \mathrm{mg}$ of $\mathrm{MgO}$ was weighed, placed into a 25 $\mathrm{mL}$ volumetric flask, and extracted with the $0.25 \%$ aqueous solution of formic acid using the ultrasonic bath for 20 minutes. The volumetric flask was filled up to the volume with the same solvent. Afterwards, the solution was filtered through Syringe Nylon Filters, 25 $\mathrm{mm}$, with $0.45 \mu \mathrm{m}$ pore size (Waters, Milford, USA) and used for the preparation of working solutions. Stock solution was diluted with $95 \mathrm{mM}$ ammonium format - acetone - acetonitrile mixture (20:16:64, v/v/v), and six solutions containing $200 \mu \mathrm{g} \mathrm{mL}^{-1}$ of $\mathrm{MgO}$ were obtained in this way.

Ten Magnezijum 375 Plus $B 6^{\circledR}$ capsule contents were pulverized, a quantity of capsule content corresponding to $5 \mathrm{mg}$ of pyridoxine $\mathrm{HCl}$ or thiamin $\mathrm{HCl}$ was placed into a $25 \mathrm{~mL}$ volumetric flask and extracted with the acetonitrile-water mixture (50:50, v/v) using the ultrasonic bath for 20 minutes. The volumetric flask was filled to the mark with the same solvent, and the solution was filtered through Syringe Nylon Filters, $25 \mathrm{~mm}$, 
with $0.45 \mu \mathrm{m}$ pore size (Waters, Milford, USA). Diluting that stock solution with $95 \mathrm{mM}$ ammonium format - acetone - acetonitrile mixture $(20: 16: 64, \mathrm{v} / \mathrm{v} / \mathrm{v})$, six solutions containing $80 \mu \mathrm{g} \mathrm{mL}^{-1}$ of pyridoxine $\mathrm{HCl}$ and thiamin $\mathrm{HCl}$ were prepared.

\section{Results and discussion}

Within the registry of dietary supplements (13), various products comprising merely magnesium or its combination with the B complex vitamins are listed. Considering the growing dietary supplement commercial market and the safety concerns, quality and efficacy of these products, as well as a precise and accurate assay of active compounds in these products, are of utmost importance. Therefore, the main goal of this research was to develop the Hydrophilic Interaction Liquid Chromatography - Photodiode array - Charged Aerosol Detector (HILIC-PDA-CAD) method for the determination of magnesium, thiamine and pyridoxine in Magnezijum 375 Plus B6 marketed dietary supplement following the Analytical Quality by Design (AQbD) principles.

In the first step. the influence of salt concentration in the aqueous part of the mobile phase $\left(\mathrm{x}_{1}\right), \mathrm{pH}$ value of the aqueous part of the mobile phase ( $\left.\mathrm{x}_{2}\right)$ and salt type $\left(\mathrm{x}_{3}\right)$ were investigated by I-optimal experimental design towards retention behavior of the abovementioned analytes. These parameters were denoted as critical method parameters (CMPs) according to the QbD terminology. Under the experimental conditions presented in Table I, pyridoxine was eluting first, followed by chloride anion $\left(\mathrm{Cl}^{-}\right)$and thiamine, while magnesium cation $\left(\mathrm{Mg}^{2+}\right)$ was the last eluting compound. Two critical peak pairs, pyridoxine $/ \mathrm{Cl}^{-}$and $\mathrm{Cl}^{-}$/ thiamine, were distinguished by CAD. Consequently, selectivity factors of the defined critical peak pairs $\left(\alpha_{\mathrm{B} 6 / \mathrm{Cl},}, \alpha_{\mathrm{Cl} / \mathrm{B} 1}\right)$ and $\mathrm{Mg}^{2+}$ retention factor $\left(k_{\mathrm{Mg}}\right)$ were originally adopted as critical method attributes (CMAs). However, the analysis of solutions for selectivity evaluation indicated co-elution of thiamine and lactose that is excipient with an intensive CAD response. Therefore, we decided to employ PDA for the thiamine determination at $220 \mathrm{~nm}$, and to use Design Space (DS) computation for $\alpha \mathrm{B} 6 / \mathrm{Cl}$ and $k_{\mathrm{Mg}}$ as the CMAs. The experimentally obtained CMA values are provided in Table I.

Logarithmic transformation of $k_{\mathrm{Mg}}$ and power transformation of $\alpha \mathrm{B} 6 / \mathrm{Cl}$ preceded the mathematical model construction. For $\ln k_{\mathrm{Mg}}$ and $\alpha_{\mathrm{B} 6 / \mathrm{Cl}}{ }^{-2.89}$, a linear model with two factor interactions and quadratic model were obtained, respectively. The ANOVA test, lack-offit test and determination coefficients $\left(R^{2}\right.$, adjusted $R^{2}$ - adj. $R^{2}$ and predicted $R^{2}$ - pred. $\mathrm{R}^{2}$ ) confirmed the adequacy of the obtained models. The mathematical model coefficients were calculated for coded factor values and their values, statistical significance, lack-offit, $\mathrm{R}^{2}$, adj. $\mathrm{R}^{2}$ and pred. $\mathrm{R}^{2}$ are presented in Table II. From the derived mathematical models for each level of qualitative factor salt type (ammonium format (AF) - lower level, ammonium acetate (AA) - upper level), separate mathematical models were computed. The equations $1-2$ and $3-4$ relate CMPs and CMSs when AF and AA are used, respectively.

$$
\begin{gathered}
\alpha_{\mathrm{B} 6 / \mathrm{Cl}}{ }^{-2,89}=0,0312-0,0024 \mathrm{x}_{1}-0,0016 \mathrm{x}_{2}+0,0044 \mathrm{x}_{1} \mathrm{x}_{2}-0,0133 \mathrm{x}_{1}^{2} \\
\ln k_{\mathrm{Mg}}=3,2668-0,7278 \mathrm{x}_{1}+0,3003 \mathrm{x}_{2}
\end{gathered}
$$




$$
\begin{gathered}
\alpha_{\mathrm{B} 6 / \mathrm{Cl}}{ }^{-2,89}=0,0493-0,0139 \mathrm{x}_{1}+0,0165 \mathrm{x}_{2}+0,0044 \mathrm{x}_{1} \mathrm{x}_{2}-0,0133 \mathrm{x}_{1}^{2} \\
\ln k_{\mathrm{Mg}}=3,7637-1,2150 \mathrm{x}_{1}+1,1376 \mathrm{x}_{2}
\end{gathered}
$$

Table II Coefficients of estimated models calculated for coded factor values and their statistical significance

Tabela II Koeficijenti modela izračunati za kodirane vrednosti faktora i statistički značajni

\begin{tabular}{|c|c|c|c|c|}
\hline & \multicolumn{2}{|c|}{$\alpha_{B 6 / C l} l^{-2,89}$} & \multicolumn{2}{|c|}{$\ln k_{M g}$} \\
\hline & coefficient & $p^{*}$ & coefficient & $p^{*}$ \\
\hline$b_{0}$ & 0.0403 & - & 3.5152 & - \\
\hline$b_{1}$ & -0.0082 & $0.0005^{*}$ & -0.9714 & $<0.0001^{*}$ \\
\hline$b_{2}$ & 0.0074 & $0.0009 *$ & 0.7190 & $<0.0001^{*}$ \\
\hline$b_{3}$ & 0.0091 & $<0.0001^{*}$ & 0.2485 & $0.0007^{*}$ \\
\hline$b_{1} b_{2}$ & 0.0044 & 0.0842 & 1 & 1 \\
\hline$b_{1} b_{3}$ & -0.0058 & $0.0048^{*}$ & -0.2436 & $0.0074 *$ \\
\hline $\boldsymbol{b}_{2} \boldsymbol{b}_{3}$ & 0.0091 & $0.0002 *$ & 0.4186 & $0.0001 *$ \\
\hline$b_{1}^{2}$ & -0.0133 & $0.0002 *$ & 1 & 1 \\
\hline$b_{2}{ }^{2}$ & l & l & I & I \\
\hline$R^{2}$ & \multicolumn{2}{|c|}{0.9469} & \multicolumn{2}{|c|}{0.9549} \\
\hline $\operatorname{adj} . R^{2}$ & \multicolumn{2}{|c|}{0.9098} & \multicolumn{2}{|c|}{0.9361} \\
\hline pred. $R^{2}$ & \multicolumn{2}{|c|}{0.7921} & \multicolumn{2}{|c|}{0.8893} \\
\hline
\end{tabular}
parametri dobijeni analizom varijanse

* statistically significant coefficients for $\mathrm{p}<0.05$

$b_{0}$ is the intercept. $b_{1}, b_{2}$ and $b_{3}$ are the coefficients of main effect terms $x_{1}, x_{2}$ and $x_{3}$ respectively, $b_{12}, b_{13}$ and $b_{23}$ are coefficients of the interaction terms. $b_{1}{ }^{2}, b_{2}{ }^{2}$ and $b_{3}{ }^{2}$ are coefficients of quadratic terms

$k_{\mathrm{Mg}}, \alpha_{B 6 / C l}$ - same as in Table I caption

The negative sign of the coefficients corresponding to $\mathrm{x}_{1}$ suggests a decrease in both the separation of the critical peak pair and retention of $\mathrm{Mg}^{2+}$, with an increase in salt concentration in the aqueous phase. Conversely, the positive sign of the coefficients corresponding to $\mathrm{x}_{2}$ indicates the opposite effect of $\mathrm{pH}$ of the aqueous phase, leading to a prolonged chromatographic run and better separation at higher $\mathrm{pH}$ values. The absolute values of the calculated coefficients suggest that the influence of salt concentration in the aqueous phase is more profound on both $k \mathrm{Mg}$ and $\alpha \mathrm{B} 6 / \mathrm{Cl}$ compared to the $\mathrm{pH}$ of the aqueous phase. 
For the computation of 2D-DS, the limits were set for the selected CMAs $\alpha \mathrm{B} 6 / \mathrm{Cl}>$ 3.5 and $k_{\mathrm{Mg}}<4$ with the probability $\pi=95 \%$. Experimental space was gridded by the factor value discretization in the following manner: the salt concentration [50:2.5:100] and the $\mathrm{pH}$ value [4.25:0.075:5.75].

In the next step, Monte Carlo simulations with 5000 iterations in each of 21 points for salt concentration $\times 21$ points for $\mathrm{pH}$ of the aqueous phase $=441$ grid points were performed. The distribution of $\alpha \mathrm{B} 6 / \mathrm{Cl}$ and $k \mathrm{Mg}$ for each grid point was obtained by the adding of the uniform error distribution equal to the calculated standard error to the model coefficient estimates. Eventually, the region of experimental domain, comprising the values of $\alpha_{\mathrm{B} 6 / \mathrm{Cl}}$ and $k_{\mathrm{Mg}}$ that met the defined criteria with the desired quality level $(\pi \geq 95 \%)$, was determined and illustrated in Figure 1A for AF and Figure 1B for AA. From the results obtained for AF, a larger DS was constructed covering a wider range of chromatographic conditions, and it was used for working point selection. CMPs corresponding to working point were $95 \mathrm{mM} \mathrm{AF}$ in the aqueous phase with $\mathrm{pH}$ adjusted at 4.4. A verification experiment was conducted and the experimentally obtained CMAs were $\alpha_{\mathrm{B} 6 / \mathrm{Cl}}=3.74$ и $k_{\mathrm{Mg}}=2.36$. The corresponding chromatogram is given in Figure 2. 
A.

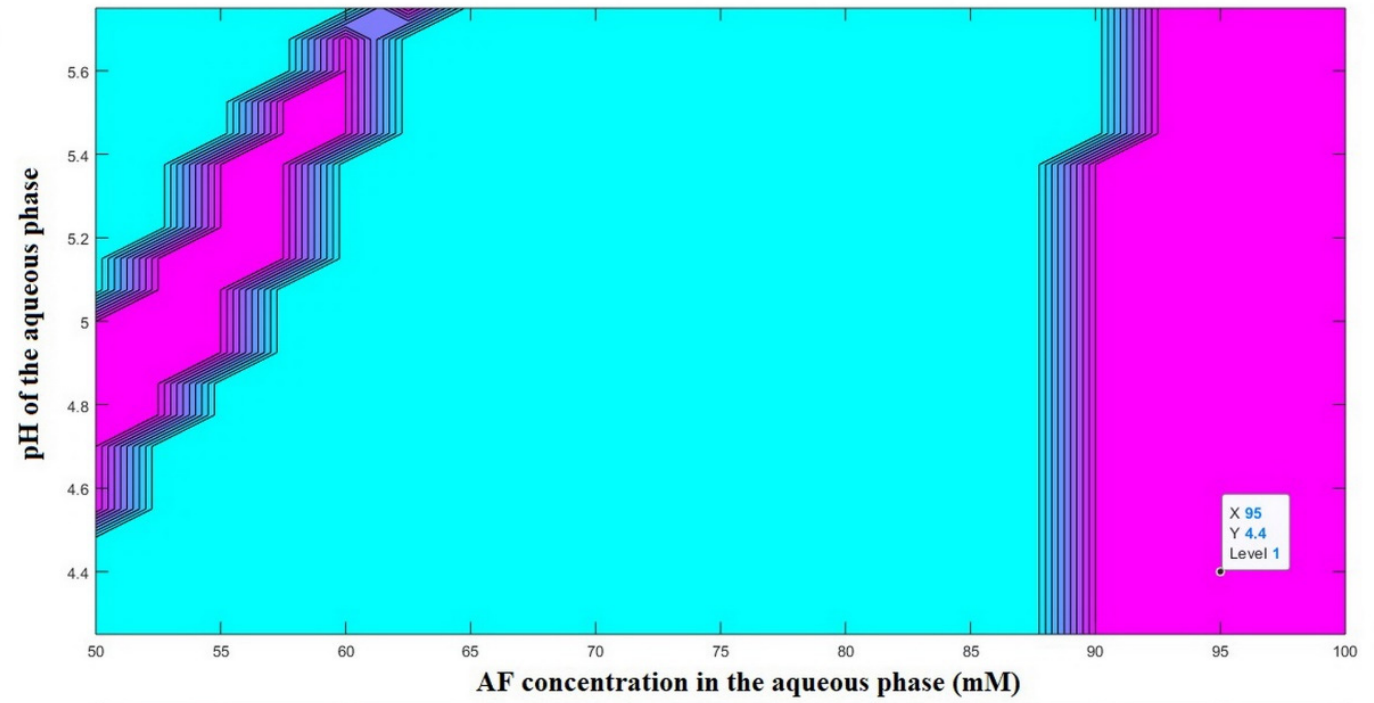

B.

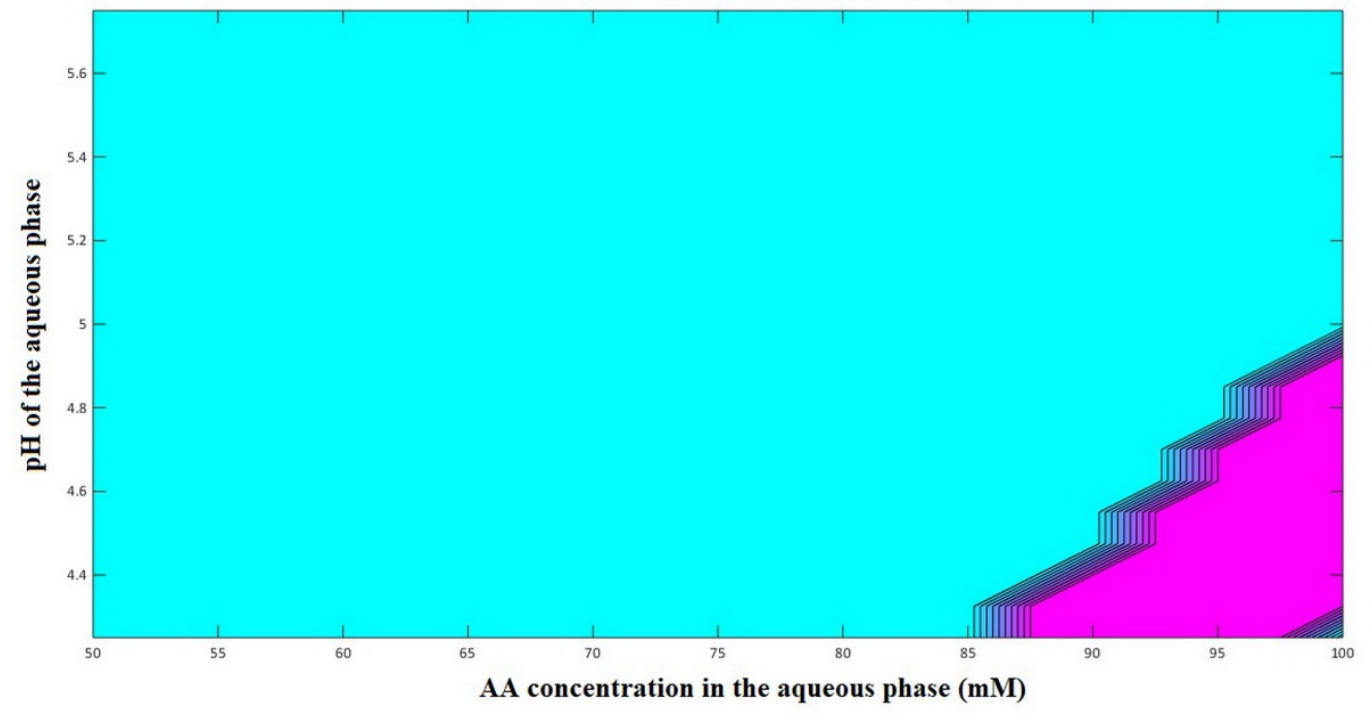

Figure 1. 2D representation of DS for predefined CMAs $\left(\alpha_{\mathrm{B} / \mathrm{Cl}}>3.5\right.$ and $\left.\boldsymbol{k}_{\mathrm{Mg}}<4\right)$ achieved with probability $\pi \geq 95 \%$. The pink part represents the region of design space where the working point should be selected from.

A. AF in the aqueous part of mobile phase, B. AA in the aqueous part of mobile phase

Slika 1. 2D prikaz DS za utvrđene CMAs $\left(\alpha_{\mathrm{B} 6 / \mathrm{Cl}}>3,5\right.$ and $\left.\boldsymbol{k}_{\mathrm{Mg}}<4\right)$ konstruisan za verovatnoću $\pi \geq 95 \%$. Region roze boje odgovara delu dizajna prostora iz koga treba odabrati radnu tačku.

A. AF u vodenoj fazi, B. AA u vodenoj fazi 
A.
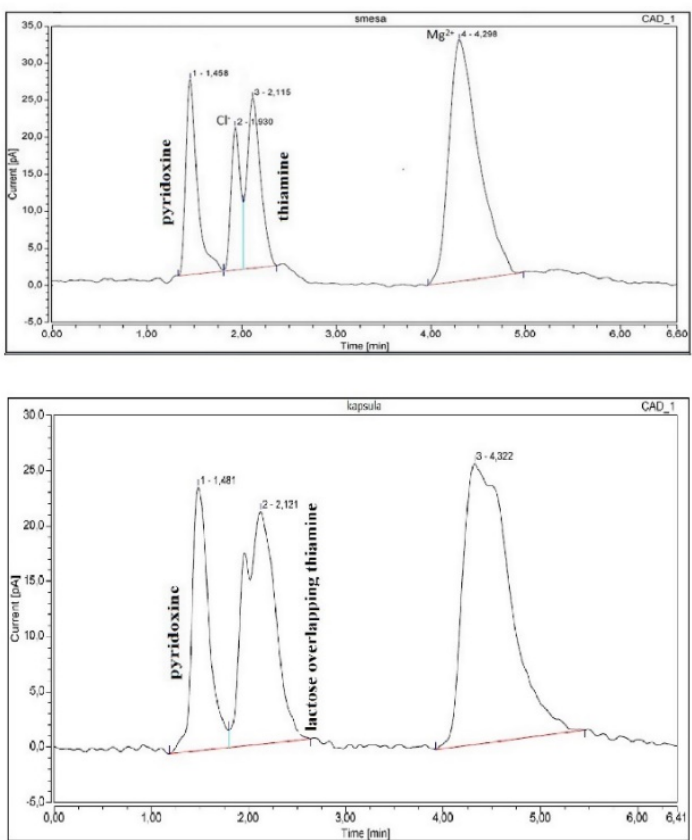

C.

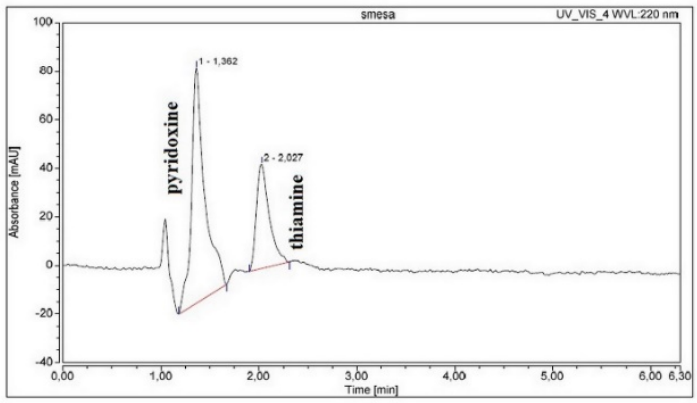

Figure 2. A. CAD chromatogram of mixture containing $200 \mu \mathrm{g} / \mathrm{mL} \mathrm{of} \mathrm{MgO}$ and $100 \mu \mathrm{g} \mathrm{mL}^{-1}$ of both vitamins: $\mathrm{MgO}(\mathrm{tr}=4.298 \mathrm{~min}$.), pyridoxine $(\operatorname{tr}=1.458 \mathrm{~min})$ and thiamine $(\operatorname{tr}=2.115 \mathrm{~min})$, B. CAD chromatogram of sample solution containing $80 \mu \mathrm{g} \mathrm{mL}^{-1}$ of both vitamins $\mathrm{MgO}$ $(t r=4.322 \mathrm{~min}$.), pyridoxine $(\mathrm{tr}=1.481 \mathrm{~min})$ and lactose overlapping thiamine (tr $=2.121 \mathrm{~min})$ and $\mathrm{C}$. UV chromatogram of mixture containing $100 \mu \mathrm{g} \mathrm{mL}^{-1}$ of both vitamins at $220 \mathrm{~nm}$ : pyridoxine $(\mathrm{tr}=1.362 \mathrm{~min})$ and thiamine ( $t r=\mathbf{2 . 0 2 7} \mathbf{m i n}$ ) recorded under conditions given by the working point: $95 \mathrm{mM} \mathrm{AF}$ in the aqueous phase with $\mathrm{pH}$ adjusted at 4.4

Slika 2. A. CAD hromatogram smeše koja sadrži $200 \mu \mathrm{g} / \mathrm{mL}$ of $M g O$ i $100 \mu \mathrm{g} \mathrm{mL}{ }^{-1}$ oba vitamina: $\mathrm{MgO}(\operatorname{tr}=4,298 \mathrm{~min}$.), piridoksin $(\operatorname{tr}=1,458 \mathrm{~min})$ i tiamin $($ tr $=2,115 \mathrm{~min})$, B. CAD hromatogram rastvora uzorka koji sasrži $80 \mu \mathrm{g} \mathrm{mL}^{-1}$ oba vitamina $\mathrm{MgO}(\mathrm{tr}=4,322 \mathrm{~min}$.), piridoksin $(\mathrm{tr}=1,481 \mathrm{~min})$ i laktoza koeluirana sa tiaminom $(\mathrm{tr}=2,121 \mathrm{~min})$ i C. UV hromatogram smeše koja sadrži $100 \mu \mathrm{g} \mathrm{mL}^{-1}$ oba vitamina na $220 \mathrm{~nm}$ : piridoksin $(t r=1,362 \mathrm{~min})$ i tiamin $(\mathrm{tr}=2,027 \mathrm{~min})$ snimljeni pod uslovima definisanim radnom tačkom: $95 \mathrm{mM}$ AF u vodenoj fazi čija je pH vrednost podešena na 4.4 
Finally, the one-factor-at-a-time approach was applied to the maximization of pyridoxine and $\mathrm{Mg}^{2+} \mathrm{CAD}$ response. The influence of evaporation temperature was evaluated at $35^{\circ} \mathrm{C}$ and $50^{\circ} \mathrm{C}$ level and it led to the conclusion that the higher temperature provides a more intense response. Experiments were also conducted at various levels of filter constant $(0,1 \mathrm{~s}, 5 \mathrm{~s}$ and $10 \mathrm{~s})$, gas pressure (40 psi, 50 psi and $60 \mathrm{psi})$ and data collection rate $(1 \mathrm{~Hz}, 10 \mathrm{~Hz}$ and $100 \mathrm{~Hz})$ as well. The response increases with the rise in gas pressure, base line is smoother at higher values of filter constant, while the change of data collection rate from $10 \mathrm{~Hz}$ to $100 \mathrm{~Hz}$ did not lead to improvement of peak shape or enlargement of the peak area. Eventually, CAD parameters were set at the following values: evaporation temperature $50^{\circ} \mathrm{C}$, gas pressure $60 \mathrm{psi}$, data collection rate $10 \mathrm{~Hz}$ and filter constant $10 \mathrm{~s}$.

Method performance qualification was performed by testing the suitability of the developed method via selectivity, linearity, accuracy and precision evaluation. The exact list of excipients in Magnezijum 375 Plus B $6^{\circledR}$ was not available, since the manufacturer only vaguely reported the presence of an anti-caking agent. Therefore, for the purpose of selectivity testing, the influence of silicon dioxide was investigated (colloidal silicon dioxide or colloidal silica) because it is frequently used in solid dosage forms as an anticaking agent, adsorbent, disintegrant or glidant to allow powder to flow freely when tablets and capsules are processed. Furthermore, anhydrous lactose, which is widely used as a filler or diluent in tablets and capsules, was also tested. The interference of colloidal silica was not evidenced with either CAD or PDA. On the other hand, the lactose had an intensive CAD response and co-eluted with thiamine, while no interference was observed with PDA detection at $220 \mathrm{~nm}$. The values for calculated regression parameters and recovery values (Table III) are in agreement with the criteria for linearity and accuracy, respectively $(14,15)$. For an estimation of precision, RSDs were calculated: $\mathrm{MgO}$ $(1.22 \%)$, thiamine $(1.79 \%)$ and pyridoxine $(1.70 \%)$ and the obtained values met the defined criteria of RSD $<2 \%$ for active ingredients $(14,15)$. The content of $\mathrm{MgO}$ in the analyzed capsules was $108.5 \%$ (406.87 $\mathrm{mg}$ / caps), that of thiamine hydrochloride $75.07 \%$ ( $0.83 \mathrm{mg} /$ caps) and pyridoxine hydrochloride $101.98 \%$ (1.43 $\mathrm{mg} / \mathrm{caps})$. 
Table III Validation parameters: linearity and accuracy of the proposed HILIC-PDA-CAD method

Tabela III Validacioni parametri: linearnost i tačnost predložene HILIC-PDA-CAD metode

\begin{tabular}{|c|c|c|c|c|c|c|}
\hline \multirow[b]{2}{*}{ Substance } & \multicolumn{4}{|c|}{ Linearity } & \multicolumn{2}{|c|}{ Accuracy } \\
\hline & $\begin{array}{c}\text { Concentration } \\
\text { range }\left(\mu \mathrm{g} \mathrm{mL} \mathrm{m}^{-1}\right)\end{array}$ & $\mathrm{a}$ & $\mathrm{b}$ & $\mathrm{r}$ & $\begin{array}{l}\text { Concentration } \\
\text { level }\left(\mu \mathrm{g} \mathrm{mL} L^{-1}\right)\end{array}$ & $\begin{array}{c}\text { Recovery } \\
(\%)\end{array}$ \\
\hline \multirow{3}{*}{$\mathrm{MgO}$} & \multirow{3}{*}{$100-300$} & \multirow{3}{*}{102.8} & \multirow{3}{*}{7142.8} & \multirow{3}{*}{0.9995} & 160 & 99.24 \\
\hline & & & & & 200 & 98.98 \\
\hline & & & & & 240 & 100.01 \\
\hline \multirow{3}{*}{$\begin{array}{c}\text { Pyridoxine } \\
\mathrm{HCl}\end{array}$} & \multirow{3}{*}{$40-120$} & \multirow{3}{*}{31.465} & \multirow{3}{*}{303.32} & \multirow{3}{*}{0.9981} & 64 & 100.50 \\
\hline & & & & & 80 & 101.47 \\
\hline & & & & & 96 & 99.68 \\
\hline \multirow{3}{*}{$\begin{array}{c}\text { Thiamine } \\
\mathrm{HCl}\end{array}$} & \multirow{3}{*}{$40-120$} & \multirow{3}{*}{66.194} & \multirow{3}{*}{748.62} & \multirow{3}{*}{0.9987} & 64 & 100.09 \\
\hline & & & & & 80 & 101.21 \\
\hline & & & & & 96 & 99.27 \\
\hline
\end{tabular}

$\mathrm{a}$ - slope, $\mathrm{b}$ - intercept, $\mathrm{r}-$ correlation coefficient (acceptance value $>0.9900$ )

\section{Conclusion}

The Analytical Quality by Design approach was selected as the most appropriate in the development of the HILIC-PDA-CAD method for determination of magnesium, pyridoxine and thiamine in a dietary supplement. The organic modifier mixture comprising acetonitrile and acetone was selected as the most suitable while CMPs (salt type, concentration of the salt in the aqueous part of the mobile phase and $\mathrm{pH}$ value of the mobile phase) were optimised by the I-optimal experimental design. CMAs were the two responses distinguished as the most relevant $\left(\alpha_{\mathrm{B} 6 / \mathrm{Cl},} \mathrm{kMg}_{\mathrm{Mg}}\right.$. Mathematical models were obtained for each response, and their validity was confirmed according to ANOVA test, lack-of-fit and determination coefficients values. The 2D-DS plots were constructed for CMAs $\alpha \mathrm{B} 6 / \mathrm{Cl}>3.5$ and $k_{\mathrm{Mg}}<4$ with the probability $\pi=95 \%$. The grid point search and Monte Carlo simulations with 5000 iterations contributed to optimal condition selection according to the defined criteria. The selected working point included $95 \mathrm{mM}$ AF as part of the aqueous phase, while the $\mathrm{pH}$ value was set to 4.4. The CAD parameters that complied with the best responsiveness of pyridoxine and $\mathrm{Mg}^{2+}$ involved: evaporation temperature $50^{\circ} \mathrm{C}$, gas pressure $60 \mathrm{psi}$, data collection rate $10 \mathrm{~Hz}$ and filter constant $10 \mathrm{~s}$. The determination of thiamine by the HILIC-CAD method was prevented due to lactose signal interference. This was resolved employing PDA detection at $220 \mathrm{~nm}$, giving consideration to chromophores lacking lactose structure, resulting in no response generation in the UV wavelength range. The developed method met all the defined validation criteria set by the ICH Q2(R1). 


\section{Acknowledgment}

These results are part of the Project no. 451-03-9/2021-14/200161, financed by the Ministry of Education, Science and Technological Development of the Republic of Serbia.

\section{References}

1. 1. FDA 101: Dietary Supplements [Internet] [cited 2019 March 2]. Available from: https://www.fda.gov/consumers/consumer-updates/fda-101-dietary-supplements.

2. 2. Food safety law, The Official Gazette of the Republic of Serbia, 41/2009 and 17/2019.

3. 3. Rules on the health suitability of dietary products, The Official Gazette of the Republic of Serbia, 45/2010, 27/2011, 50/2012, 21/2015, 75/2015, 7/2017 and 103/2018.

4. 4. Magnezijum-375-plus-b6-kapsule-a100 [Internet] [cited 2019 march 2]. Available from: https://www.apotekanet.rs/magnezijum-375-plus-b6-kapsule-a100 .

5. 5. Magdalena L, Sylwia S, Aleš H, Bogusław B. Corona-Charged Aerosol Detection: An Analytical Approach. CritReviews Anal.Chem. 2013;43 (2):64-78.

6. 6. Cobb Z, Shaw P. N, Lloyd LL, Wrench N, Barrett D. Evaporative Light-Scattering Detection Coupled to Microcolumn Liquid Chromatography for the Analysis of Underivatized Amino Acids: Sensitivity, Linearity of Response and Comparisons with UV Absorbance Detection. J. Microcolumn. 2001;13:169-175.

7. 7. Moreau RA. The Analysis of Lipids via HPLC with a Charged Aerosol Detector. Lipids J. 2006;41(7):727-734.

8. 8. Vervoort, N, Daemen, D, Torok G. Performance Evaluation of Evaporative Light Scattering Detection and Charged Aerosol Detection in Reversed Phase Liquid Chromatography. J. Chromatogr. A. 2008;1189:92-100.

9. 9. Buszewski B, Noga S. Hydrophilic interaction liquid chromatography (HILIC) - a powerful separation technique. Anal Bioanal Chem. 2012;402:231-247.

10. 10. Alpert AJ. Hydrophilic-interaction chromatography for the separation of peptides, nucleic acids and other polar compounds. J Chromatogr A. 1990;499:177-196.

11. 11. Rozet E, Lebrun P, Debrus B, Boulanger B, Hubert P. Design spaces for analytical methods. Trends Anal. Chem. 2013;42,157-167.

12. 12. Ramalingam P, Kalva B,Yiragamreddy PR. Analytical Quality by Design: A Tool for Regulatory Flexibility and Robust Analytics, International Journal of Anal. Chem. doi: 10.1155/2015/868727.

13. 13. Dijetetski-proizvodi [Internet]. Ministarstvo zdravlja [cited 2019 March 6]. Available from: https://www.zdravlje.gov.rs/tekst/345415/dijetetski-proizvodi.php .

14. 14. Crowther JB, In: Ahuja S, Scypinski S, editors. Validation of pharmaceutical test methods Handbook of modern pharmaceutical analysis. New York: Academic Press; 2001; p. 415-443.

15. 15. International Conference on Harmonisation of Technical Requirements for Registration of Pharmaceuticals for Human Use - ICH. Validation of Analytical Procedures: Text and Methodology Q2 (R1). $4^{\text {th }}$ version. 2015. 


\title{
Razvoj HILIC-PDA-CAD metode za određivanje sadržaja magnezijuma, piridoksina i tiamina u dijetetskom suplementu primenom metodologije ugradnje kvaliteta u analitičku metodu
}

\section{Milena Rmandić ${ }^{1}$ Miloš Rađenović ${ }^{2}$, Jovana Stanković ${ }^{3}$, Ana Protić ${ }^{1}$,

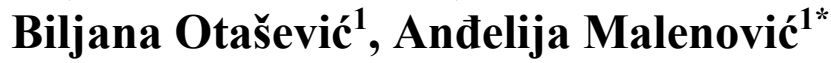

\author{
${ }^{1}$ Univerzitet u Beogradu - Farmaceutski fakultet, Katedra za analitiku lekova, \\ Vojvode Stepe 450, 11152 Beograd, Srbija \\ ${ }^{2}$ Roche d. o. o., Milutina Milankovića 11a, 11070 Beograd, Srbija \\ ${ }^{3}$ Goodwill Pharma, Matije Gupca 14, 24000 Subotica, Srbija \\ *Autor za korespondenciju: Anđelija Malenović,
}

E-mail: andjelija.malenovic@pharmacy.bg.ac.rs

\section{Kratak sadržaj}

U ovom istraživanju korišćena je metodologija ugradnje kvaliteta u metodu (AQbD) u cilju razvoja HPLC-PDA-CAD metode za određivanje magnezijuma, pirodoksina i tiamina $u$ dijetetskom suplementu. Eksperimenti su izvedeni na Dionex Ulitimate 3000 HPLC sistemu sa PDA i CAD detektorima. Razdvajanje je vršeno izokratskim eluiranjem mobilnom fazom koja je smeša acetonitrila, acetona i vodenog rastvora amonijum acetata/amonijum formijata (48:12:40, $\mathrm{V} / \mathrm{V} / \mathrm{V})$ na ZIC-HILIC PEEK koloni $(100 \times 4.6 \mathrm{~mm}, 5 \mu \mathrm{m})$. Talasna dužina detekcije bila je 220 nm. Optimalna podešavanja $\mathrm{CAD}$ su definisana jednofaktorskim pristupom i obuhvaju: temperaturu isparavanja $50^{\circ} \mathrm{C}$, filter konstantu $10 \mathrm{~s}$, pritisak gasa 60 psi. Uticaj kvalitativnih (vrsta soli) i kvantitativnih faktora ( $\mathrm{pH}$ vrednost $\mathrm{i}$ koncentracija soli) na retencioni faktor magnezijuma $\left(k_{\mathrm{Mg}}\right)$ i faktor selektivnosti piridoksina i hloridnog anjona $\left.\left(\alpha_{\mathrm{B} 6 / \mathrm{Cl}}\right)^{-}\right)$ispitan je primenom $I-$ optimizacionog dizajna. Prostor dizajna je definisan Monte Karlo simulacijom i propagiranjem greške koeficijenata dobijenih matematičkih modela sa ciljem definisanja hromatografskih uslova kod kojih su zadovoljeni sledeći kriterijumi: $k_{\mathrm{Mg}}<4$ i $\alpha_{\mathrm{B} 6 / \mathrm{Cl}}>3,5$, sa verovatnoćom $\pi=95 \%$. Iz dobijenog 2D-grafika prostora dizajna izabran je optimalni sastav vodene faze koji je obuhvatao $95 \mathrm{mM}$ amonijum formijat čija je $\mathrm{pH}$ vrednost podešena na 4,4. Metoda je validirana i dokazana je njena pouzdanost $\mathrm{u}$ rutinskoj primeni.

Ključne reči: HILIC-PDA-CAD, magnezijum, piridoksin, tiamin, AQbD 